\title{
The influence of the covid-19 epidemic on the incidence of depression in the elderly in a reference dispensary
}

\author{
Tjaša Šarić, Karin Kramberger \\ 'Community Health Centre dr. Adolfa Drolca Maribor, Maribor, Slovenia \\ ${ }^{2}$ University of Maribor, Faculty of Health Sciences, Maribor, Slovenia \\ tjasa.saric@gmail.com; karin.krambergero7@gmail.com
}

\section{Abstract}

Introduction: Depression is an increasingly common mental disorder that is already facing more than 264 million people worldwide. The effects of depression can be long-lasting and recurrent, which greatly affects the quality of life. The main strategy to combat COVID-19 in most countries around the world is social distance, which is the main cause of increasing human loneliness, resulting in depression, especially in the elderly. Certainly, social distance is an important and effective measure to contain the epidemic, but we must be aware that it has psychological consequences for people. Methods: In writing the article, we used a descriptive methodological review of the literature on the impact of the COVID-19 epidemic on the development of depression in the elderly. Literature is searched using the COBISS bibliographic system, and literature is reviewed in foreign databases such as Medline, CINAHL, PubMed, Wiley, Sicris and EBSCOhost. We searched the literature for the period from 2016 to 2021. Keywords we used were: covid-19, depression, elderly, stress, loneliness. Discussion and conclusion: We found that the elderly are more exposed to risk factors such as loneliness, stress, and social distance during the COVID-19 epidemic. These factors are the main triggers for the development of depression. Media has a great influence on mental health of the elderly, which, in addition to doing useful work, informing the public, can also have a negative impact on the public by constantly reporting the spread of the disease and the number of deaths, which can lead isolated people to despair. It has been known for years that physical pain and illness often occur due to psychological problems. Depression, however, is most often caused by severe personal distress as a result of long economic, post-war crises, and so on. However, it also occurs when people are self-isolated, lonely and forgotten by everyone for a long time. We will be able to determine for months the consequences of the COVID-19 epidemic, not only economic, 
but also psychological, because everything we experience affects our body and soul. Upon review of foreign research, we found that there is a correlation between epidemic and epidemiological measures and depression. Depression in the initial phase is often not detected in time, which indicates the need for more effective preventive treatment in the Reference dispensary of Family Medicine with screening and counseling.

Keywords: covid-19, depression, elderly, stress, loneliness

\section{Introduction}

It is a fact that the epidemic negatively affects people's mental health. The most at risk group are definitely the elderly. It is therefore crucial that the first signs of psychiatric illnesses, including depression, are detected as soon as possible to prevent their development. The nurse in the Reference Clinic plays an important role in the immediate detection, as she recognizes the first signs of depression through screening tests and interviews and, based on the findings and documentation, refers the patient to the chosen personal physician in a timely manner. According to the authors, factors such as fear of infection, inadequate information, stigma, or financial loss were associated with major negative psychological impacts. These stressors, however, increase the risk of psychopathology such as anxiety or depression (Pfferbaum \& North, 2020). The World Health Organization (WHO, 2020) in its guidelines recommends strict social isolation of the geriatric population to control death in severely affected countries. As vulnerabilities increase, so do the fears, panic, and anxiety that have been talked about but little talked about among the elderly and their families. The purpose of the article is to find a correlation between the epidemic and the development of depression in the elderly through a systematic review of the literature.

\section{Methods}

A descriptive method of work was used - literature review using the COBISS bibliographic system, and literature review in databases such as: Medline, CINAHL, PubMed, Wiley, Sicris and EBSCOhost . We searched for literature for the period 2016 to 2021 . The key words we used were: covid-19, depression, old age, stress, loneliness in Slovenian or English (covid-19, depression, elderly , stress, loneliness). The following were considered as inclusion /exclusion criteria for the selection of literature: language, professionalism of literature, accessibility of literature in its entirety and age of literature.

\section{Depression}

Epidemics have historically negatively affected the mental health of the population (GAVI, 2020). The rapid growth of confirmed cases and deaths has created distress such as stress, anxiety, and depression in the general population (Picaza Gorrochategi, et al ., 2020). Recent research has shown that infection 
with SARS-CoV-2, the virus that causes COVID-19, can affect mental health. The study, published in The Lancet Psychiatry, analyzed the electronic medical records of 69.8 million patients in the U.S., which included 62,354 patients diagnosed with COVID-19. Within three months of positive testing, nearly $20 \%$ of people diagnosed with COVID-19 were then diagnosed with psychiatric disorders, including anxiety, depression, or insomnia. One in four of these people has not yet received a psychiatric diagnosis (GAVI, 2020). A study conducted in the Netherlands shows that individuals with chronic mental health disorders reported a greater impact of the epidemic on their mental health, had more fear of COVID-19, and coping with a pandemic on their own was not effective in these people (Pan, et al., 2020). There are major concerns about the impact of the global COVID-19 outbreak on mental health. Numerous studies show that mental health deteriorated in many countries before and during forced isolation, but it remains unknown how mental health changed from week to week during the COVID-19 epidemic (Fancourt, et al., 2020). Exposure to information leveled at people by social networks and the media, however, has been linked by experts to depression ( $\mathrm{Ni}$, et al., 2020).

\section{The impact of the epidemic on mental health}

Loneliness reflects subjective distress resulting from a mismatch between desired and perceived social relationships (Jeste, et al., 2020). Unfortunately, loneliness in an individual causes distress such as depression, anxiety, physical morbidity, and mortality. Although the evidence suggests that the social distance and measures envisaged to contain COVID-19 are effective, there is also a downside. Measures have a negative effect on people in terms of psychological, social and physical health. Among the vulnerable are mainly older people - older adults with multimorbidity. Elderly patients who have more chronic conditions have been found to be more lonely, anxious, and also experience insomnia. Also, their management of chronic diseases by a doctor or nurse is impaired due to the epidemic (Yeung Shan Wong, et al., 2020). Social distance is an important public health strategy to control the spread of the virus and reduce the impact on the elderly adult population. However, this comes at a price. Loneliness is associated with countless detrimental health outcomes. Older people are therefore at greater risk for effectively managing loneliness and social isolation. In an effort to limit social distancing, closures have varied across countries (Van Orden, et al., 2020). The presence of multimorbid conditions makes the elderly more susceptible to new infections and related psychological distress (Andreas, et al., 2017). Older people are prone to social isolation, even under normal circumstances, and this problem is exacerbated in the current situation. Most of them only have a close circle of friends and family with whom they communicate regularly. As most countries enforce strict blockades to control the spread of the epidemic, this issue has become even more important for older people. If such individuals are unable to provide a regular and 
permanent supply of medication, the problems will certainly recur or the current mental state will deteriorate (Philip \& Cherian, 2020).

\section{The impact of the epidemic on mental health in Slovenia}

Peoples exhaustion due to the epidemic is a response of people to a long-lasting public health crisis, which significantly interferes with the daily life of the individual. Symptoms appear gradually, influenced by emotions, experiences, and attitudes. The severity and scale of the COVID-19 epidemic and the introduction of strict measures to prevent the spread of the infection have a very large impact on the population, including that group of people not directly affected by the virus. Exhaustion causes compensatory mechanisms in people to manage the crisis situation and thus reduce the motivation to follow the recommended self- protection measures (NIJZ, 2021). When reviewing foreign research, we found that there is a correlation between epidemic and epidemiological measures and depressive symptoms, which is in contrast to the Slovenian study (SI-PANDA, 2021), which shows that the presence of these symptoms in the 12th wave of research decreased in of all age groups, and in general it was the lowest in the age group of 65 to 74 years. Depressive symptoms in the initial phase are often not detected in time in half of the persons, which indicates the need for more effective preventive treatment in the Reference dispensary of Family Medicine with screening and counseling. In the 13th wave of the SI-PANDA survey (2021), respondents were asked about how often they felt tense, stressed or under a lot of pressure in the last 14 days. Almost a quarter of respondents $(23.3 \%)$ experienced stress on a daily or frequent basis. The experience of stress decreases with age and is the lowest in the oldest age group from 65 to 74 years, approximately $9.1 \%$. Compared to the data from the CINDI survey, which took place about a year ago, the proportions of respondents are higher a year later, as in 2020 about $7 \%$ less $(16,3 \%)$ reported that they experience stress often or on a daily basis. As expected, stress is more often experienced by respondents who show signs of depressive disorder, the majority - almost 70\% compared to those who have mental health problems $(35.3 \%$ experience stress daily or often).

\section{Depression and Reference Clinic}

Reference dispensary of Family Medicine (hereinafter RDFM) plays an important role in the earliest possible detection. Communication between the patient and members of the healthcare team is of key importance in the RDFM, as all their tasks are focused on the well- being of patients (Projektna pisarna referenčnih ambulant, 2011). The implementation of preventive activities is in the domain of RDFM, which also includes the treatment of a depressed patient. It is therefore very important that the nurse at RDFM is well educated in this area so that she can detect the signs in time and alert the doctor to this. Often at the beginning of the signs of depression, we do not notice or confuse them with other illnesses, as they often appear slowly. Every sixth person will 
suffer from depression at least once in their life (Konec Juričič, 2014). No one is immune to this disease and can be affected at any stage of life. One of the reasons for the development of depression is also stress (Khan \& Khan, 2017). Appropriate treatment should be started as soon as possible, as this is how we can overcome depression (Berkow , 2005). Many times a patient with depression in the clinic complains of physical symptoms. Thus, we can conclude that these are the main reason why depressed individuals come to the family doctor at all (Strbad, 2012). The PHQ-9 scale is used in RDFM to aid in detection. The questionnaire was designed specifically for primary care and is also a diagnostic tool that can be used to monitor the adequacy of treatment. The main task of the nurse in RDFM is to determine disease exacerbation (Rifel, 2017). Treatment of a chronic patient with depression by the nurse in RDFM includes: treatment procedure - application of the PHQ-9 questionnaire; situation assessment and evaluation - evaluation of the questionnaire; conclusion (motivational conversation, information, health education, assessment of the patient's understanding of information, referral to a doctor, documentation, entry of results and health services) (Panikvar Žlahtič , et al ., 2016). When the nurse in RDFM deems it necessary to include the patient in psychoeducational workshops entitled Support in Coping with Depression, conducted by the Center for Health Promotion (CKZ), it does so. Workshops are held once a week and include counseling. During the epidemic, workshops take the form of telephone counseling. It is intended to identify the factors of depression, participants learn about the signs and symptoms, learn about the types of therapy, it is intended to increase flexibility of thinking and aimed at preventing exacerbations and great emphasis on non-activation with the support of relatives (Roškar \& Tančič Grum, 2016). We reviewed statistical data in one of the Reference dispensary of Family Medicine dr. Adolfa Drolca Maribor from November 2019 to January 2020, and compared them with data from November 2020 to January 2021. Data were obtained using the PHQ-9 questionnaire. Respondents were over 60 years of age, there were 60 respondents in both groups, and the results showed that in the period from November 2019 to January 2020, 3.3 $\%$ had risk factors for developing depression. The results from the period from November 2020 to January 2021 show that $18.3 \%$ of respondents had risk factors for the development of depression. From this, we concluded that the risk increased by $15 \%$ during the COVID-19 epidemic.

\section{Discussion}

Examining the results of foreign research in the field of the presence of a risk of developing depression during an epidemic, we see that the risk of developing depression increases significantly during an epidemic, especially with the introduction of "lockdown". Research (Ettman, 2020) showed that the prevalence of depressive symptoms in the U.S. increased more than three times during the COVID-19 epidemic, from $8.5 \%$ before COVID-19 to $27.8 \%$ during COVID-19. We humans are social beings who need contact, closeness, and when measures 
like lockdown are introduced, it is broken. That's when people become lonely, and loneliness is often the trigger for depression. During an epidemic, there is a lot of negative information that increases stress in people, so it is very important how the government of each country provides information to people. The elderly are the most vulnerable group of people, who are much more exposed to loneliness even under normal conditions than younger people. It is therefore necessary that we pay special attention to this group. Gerst-Emerson \& Jayawardhana (2015) state that social relationships are essential for people's well-being and research consistently documents that social integration and support have a protective effect on morbidity and mortality. An important role can also be played by the nurse in the Reference dispensary of Family Medicine, who detects the first signs through screening tests and counseling (Projektna pisarna referenčnih ambulant, 2011). For many, the doctor-patient relationship is one that provides social support and not just treatment. This possible explanation is confirmed by research confirming that people who are lonely do not visit a doctor for medical reasons, but to satisfy their needs for interaction and interpersonal stimulation (Gerst-Emerson \& Jayawardhana, 2015).

\section{Conclusion}

The main strategy in the fight against COVID-19 is social distancing and this is the main cause of depression. It is important that primary health care is included in the Reference Outpatient Clinics and that preventive activities are carried out, including the treatment of a depressed patient. In this way, it can detect the signs in time and prevent the development of depression. Experience from previous pandemics, such as SARS, has shown that regular telephone counseling, family contact, relevant and up-to-date information, care for general health and psychological needs, and respect for privacy and dignity are important components of mental health care ( $\mathrm{Wu}$, et al., 2009). We believe that the nurse in the referral clinic is key to detecting signs of depression, as patients usually go for regular check-ups in the referral clinic every year, which allows the nurse to recognize patients and detect possible abnormalities.

\section{References}

ANDREAS, S., SHULZ, H. \& VOLKERT, J., 2017. Prevalence of mental disorders in elderly people: the European MentDis_ICF65+ study. British Journal of Psychiatry, 210(2), pp. 125-131.

BERKOW, R., 2005. Veliki zdravstveni priročnik za domačo uporabo: najpopolnejši pregled medicinskih informacij. Ljubljana: Mladinska knjiga.

ETTMAN, K. K., ABDAllA, S. M. \& COHEN, G. H., 202o. Prevalence of Depression Symptoms in US Adults Before and During the COVID-19 Pandemic. Original Investigation, 3(9), p. 2019686.

FANCOURT, D., STEPTOE, A. \& BU, F., 2020. Trajectories of anxiety and depressive symptoms during enforced isolation due to COVID-19 in Eng- 
land: a longitudinal observational study. The Lancet Psychiatry, 8(2), pp. 141-149.

GAVI, 2020. Anxiety, depression and insomnia: the impact of COVID-19 on mental health. [Online] Available at: https://www.gavi.org/vaccineswork/anxiety-depression-and-insomnia-impact-covid-19-mental-health [Accessed 2512021 ].

GERST-EMERSON, K. \& JAYAWARDHANA, J., 2015. Loneliness as a Public Health Issue: The Impact of Loneliness on Health Care Utilization Among Older Adults. American Journal of Public Health, 105(5), pp. 10131019.

JESTE, D. V., LEE, E. E. \& CACIOPPO, S., 2020. Battling the modern behavioral epidemic of loneliness: Suggestions for research and interventions. JAMA Psychiatry, 77(6), pp. 553-554.

KHAN , S. \& KHAN, R., 2017. Chronic stress leads to anxiety and depression. Annalls of Psychiatry and Mental Health, 5(1), p. 1091.

KONEC JURIČIČ, N., 2014. Duševno zdravje: depresija. [Online] Available at: https://www.nijz.si/sl/depresija [Accessed 281 2021].

NI, M. Y., YANG, L. \& LEUNG, C. M., 2020. Mental health, risk factors, and social media use during the COVID-19 epidemic and cordon sanitaire among the community and health professionals in Wuhan, China. Journal of Medical Internet Research, 7(5), pp. 476-480.

NIJZ, 2021. Pandemija COVID-19 v Sloveniji. [Online] Available at: https:// www.nijz.si/sites/www.nijz.si/files/uploaded/panda_porocilo_po_4._valu.pdf [Accessed 135 2021].

PANIKVAR ŽLAHTIČ, K., VIDMAR, I., ISTENIČ, B. \& BENKOVIČ, R., 2016. Določitev zdravstvenih storitev diplomirane medicinske sestre v referenčni ambulanti - dopolnitev opisov. Ljubljana: Zbornica zdravstvene in babiške nege Slovenije - Zveza strokovnih društev medicinskih sester.

PAN, K.-Y., KOK, A. A. L. \& EIKELENBOOM, M., 2020. The mental health impact of the COVID-19 pandemic on people with and without depressive, anxiety, or obsessive-compulsive disorders: a longitudinal study of three Dutch case-control cohorts. The Lancet, 8(2), pp. 121-129.

PFFERBAUM, B. \& NORTH, C. S., 2020. Mental Health and the Covid-19 Pandemic. New England Journal of Medicine, 383(6), pp. 510-512.

PHILIP, J. \& CHERIAN, V., 2020. Impact of COVID-19 on mental health of the elderly. International Journal Of Community Medicine And Public Health, 7(6), pp. 2435-2436.

PICAZA GORROCHATEGI, M., EIGUREN MUNITIS, A. \& DOSIL SANTAMARIA, M., 2020. Stress, anxiety, and depression in people aged over 60 in the COVID-19 outbreak in a sample collected in Northern Spain. The American journal of geriatric psychiatry, 28(9), pp. 993-998. 
PROJEKTNA PISARNA REFERENČNIH AMBULANT, 2011. Referenčna ambulanta družinske medicine. [Online] Available at: http://www.referencna-ambulanta.si/ [Accessed 281 2021].

RIFEL, J., 2017. Preventivni pregled na področju depresije. V: J. Govc Eržen \& M. Petek Šter, eds. Priročnik za zdravnike družinske medicine: izvajanje integrirane preventive kroničnih nalezljivih bolezni v referenčnih ambulantah družinske medicine. Ljubljana: Nacionalni inštitut za javno zdravje, pp. 8o-83.

ROŠKAR, S. \& TANČIČ GRUM, A., 2016. Psihoedukativne delavnice podpore pri spoprijemanju z depresijo. V: N. Konec Jurčič, S. Roškar \& P. Jelenko Roth, eds. Prepoznavanje in obravnava depresije in samomorilnosti pri pacientih v ambulanti družinskega zdravnika: priročnik za strokovnjake na primarni zdravstveni ravni. Ljubljana: Nacionalni inštitut za javno zdravje, pp. 81-86.

ㅇ $\quad$ STRBAD, E., 2012. Ali depresija boli?. Farmacevtski vestnik, 63(1), pp. 38-39.

VAN ORDEN, K. A., BOWER, E. \& LUTZ, J., 2020. Strategies to promote social connections among older adults during 'social distancing' restrictions. The American Journal of Geriatric Psychiatry, 54(4), pp. 376-38o.

WU, P., FANG, Y. \& GUAN, Z., 2009. The psychological impact of the SARS epidemic on hospital employees in China: exposure, risk perception, and altruistic acceptance of risk. The Canadian Journal of Psychiatry, 54(5), pp. 302-311.

WORLD HEALTH ORGANIZATION, 2020. Depression. [Online] Available at: https://www.who.int/health-topics/depression\#tab=tab_1 [Accessed 26 1 2021].

YEUNG SHAN WONG, S., ZHANG, D. \& WING SHAN SIT, R., 2020. Impact of COVID-19 on loneliness, mental health, and health service utilisation: a prospective cohort study of older adults with multimorbidity in primary care. British Journal of General Practice, 70(700), pp. 818-824. 